\title{
MONITORING AND EVALUATION OF THE COMPONENTS OF STATE REGULATORY INFLUENCE ON THE ACTIVITY OF BANKS IN UKRAINE
}

\author{
Dmytro Artemenko'
}

\begin{abstract}
The purpose of the study is to enhance the scientific-theoretical foundations and to develop recommendations for the formation of a comprehensive regulatory impact of the state on the activities of banks. The main objectives of the study were: determination of the organizational and economic essence of the regulatory influence of the state on the activities of banks; classification of components of complex regulatory influence; determination of indicators for monitoring methodological approaches to the assessment of the target criterion of regulatory impact; classification of measures to monitor the effectiveness of the complex regulatory impact of the state on the activities of banks. The research methodology was based on the use of the following methods: historical, system analysis and synthesis, induction and deduction, logical and mathematical modeling and discriminant analysis. The subject of the study are the mechanisms of implementation of a comprehensive regulatory impact of the state on the activities of banks. Conclusions. The main result of the study is a conceptual approach to the formation of a comprehensive regulatory impact of the state on the activities of banks, which, unlike existing ones, ensures the stable operation of banks with timely fulfillment of obligations to depositors, shareholders and creditors, which makes it impossible to conduct artificial bankruptcy with the withdrawal of liquid assets. Implementation. Logico-structural scheme of forming the target criterion of complex regulatory impact of the state on the banks' activities is based on the results of a discriminant analysis of the financial condition and bankruptcy risk of twenty banks in Ukraine. Calculated in accordance with the stages of systemic assessment, the target criterion of the complex regulatory impact of the state on banking activity is a more reliable lever, allowing for more informed decisions to maintain the effective functioning and stable development of the bank by the state, owners, managers and investors.
\end{abstract}

Key words: monitoring, monitoring of results, evaluation, assessment.

JEL Classification: O38, B23, G28

\section{Introduction}

At the beginning of 2014, the banking sector in Ukraine consisted of 180 banks. Over the past seven years, more than a hundred domestic banks have left the banking services market, including the backbone banks: PJSC CB Nadra, JSC Bank Finance and Credit, JSC Delta Bank, JSC Brockbusinessbank, JSC VTB Bank.

The main cause of bankruptcy in the banking business is the lack of timely comprehensive regulatory influence of the state on banks, which would include not only economic standards of the National Bank of Ukraine, but also leading indicators for monitoring and evaluating their financial stability and bankruptcy risk and

Corresponding author:

${ }^{1}$ LLC "Investment and Legal Group", Ukraine

E-mail: d.artemenko@a-ilg.com

ORCID: https://orcid.org/0000-0003-4947-2175 standard measures of control of the effectiveness of regulatory influence.

Beginning in 2021, the national regulator introduced a net stable funding ratio (NSFR) in addition to the short-term liquidity ratio (H6) as part of prudential supervision. However, the development of the crisis in the banking sector makes it necessary to recognize the level of their financial condition and the degree of bankruptcy risk as the leading indicators of banks' financial stability, and the market value of banks as their inherent characteristic in the banking market as the target criterion of regulatory impact.

Real-time assessment of the financial stability of the bank serves as a measurement, the results of 
which are the basis for justifying a comprehensive regulatory impact through decision-making by the national banking regulator in the NBU indicative management system, the interim administration of the Deposit Guarantee Fund to take measures to maintain its financial condition, adequate to the current market conditions; substantiation of the strategy and tactics of the bank's behavior in the market of financial services; more accurate clarification of the risks of interaction with counterparties; about reorganization, merger, acquisition or liquidation.

The formulation of the research problem was to substantiate the general logical scheme, which would include the following: first, a qualitative analysis of the financial stability of the bank in order to determine the degree of risk of bankruptcy; second, the assignment of the bank to the appropriate group of banks with unsatisfactory or satisfactory financial condition and acceptable or unacceptable risk of bankruptcy; third, the choice and application of appropriate methodological approach and methods of assessment of leading indicators and the target criterion of complex regulatory impact.

\section{The essence of the regulatory impact of the state on the activities of banks}

Consideration and disclosure of the organizational and economic essence of the regulatory impact of the state on the activities of banks is based on the scientific and methodological provisions of the theory of value through an epistemological analysis of the ratios of "evaluation", "value" and "price". The working hypothesis of the study was to recognize the market value of banks as the target criterion of the regulatory impact of the state on their activities, and the leading indicators of regulatory impact, that is, the level of financial condition and bankruptcy risk of banks determined on the basis of dynamic models of discriminant analysis.

The systematization of its market characteristics as an economic category contributed to the definition of the essence of regulatory impact as part of the mechanism of implementation of state regulatory policy on the activities of banks.

The achievement of harmony in economic relations between the subjects of supply and demand for banking services, as a theoretical hypothesis of the study, was provided by the processes and procedures for monitoring and evaluation of the market value of banks as the target criteria for the regulatory impact on their activities.

The main task of proving the theoretical and working hypothesis of the study was the quantitative and qualitative definition of the elements, attributes and properties of the market value of the bank as an economic category: structure, subject, object, principles, criteria, purpose, main objectives, social status, factors and main source (Artemenko, 2019).

The first task of the study to achieve its purpose within the subject and object contributed to the identification of certain elements, attributes and properties of market characteristics of the target criterion of the complex regulatory impact of the state on the activities of banks.

First of all, correspondence between supply and demand (economic property); achievement of consistency of economic interests between subjects (evaluation principles); ensuring achievement of satisfaction of economic interests between subjects (evaluation criteria); harmonization of economic relations between subjects of demand and supply (evaluation goal); quantitative and qualitative evaluation of demand and supply (the main objectives of evaluation); conditions of institutionalization and implementation of the activities of demand and supply entities (evaluation factors).

Comprehensive regulatory impact versus current regulatory impact should include not only the economic standards of the national regulator, but also leading indicators, target criteria, and standard measures (Artemenko, 2021; Lyashenko, 2012).

\section{Components of complex regulatory influence}

The National Bank of Ukraine monitors economic ratios of capital, credit risk, liquidity, investment and currency risks in order to ensure stable operation of banks and timely fulfillment of obligations to depositors, and to prevent misallocation of resources and loss of capital due to risks inherent in banking activities (Verkhovna Rada of Ukraine, 1999; Basel III, 2013).

Economic standards are the basis for prudential supervision in the banking sector of the national economy. However, tracking the economic standards of individual banks should be supplemented by methods and models of dynamic 
discriminant analysis, which allow tracking and predicting the financial condition of banks and bankruptcy risks (Osadcha, Artemenko, 2020; Wallison, 2011; European Central Bank, 2014).

In the context of institutional regulation of market value assessment of banks in Ukraine, national standards define both individual concepts, in particular the concept of market value as a target criterion of regulatory impact on banking activities, and the procedure for their evaluation:

- methodological approaches and peculiarities of evaluation depending on its purpose, requirements to the content of the property and business evaluation report;

- the procedure for its review and application of methodical approaches to the determination of non-market types of property value;

- the obligation to monitor the effectiveness of regulatory impact on its implementation by the subjects of evaluation activities in the assessment of property and businesses of all forms of ownership and in any case.

Processes and procedures for assessing the criterion of complex regulatory impact on banking activities are carried out in accordance with the principles that determine the socio-economic factors and patterns of its formation, as well as development trends. These are the principles of utility, supply and demand, substitution, expectation, marginal productivity of contribution, and most efficient use.

The target criterion for comprehensive regulatory impact on banking activity as an organic component of state regulatory policy in the sphere of banking services should be the market value of banks, and under the leading indicators of the implementation mechanism, the level of financial condition and bankruptcy risk.

\section{Indicators for monitoring methodological approaches to the assessment of the target criterion of regulatory impact}

The procedures used in monitoring and evaluation, aimed at determining and quantifying the usefulness of the estimated object, which is expressed by the numerical value of one of the methodical approaches to assessing the market value of banks: income, comparative, property and option.

Monitoring indicators is the collection and analysis of data on predetermined quantitative and qualitative indicators to determine the state of the system, project, process, product, service, program.

Monitoring allows the accumulation of necessary information for evaluation and contributes to the timely development of new and optimization of existing solutions.

The first edition of the Glossary of Monitoring and Evaluation Terms was published by the Ukrainian Association for Evaluation of Policies, Programs and Projects (UAO) in 2014 with the assistance of the Swiss Cooperation Office in Ukraine and the NGO Center "Social Indicators" within the project "Development and approval of basic terms for monitoring and evaluation in Ukraine".

The second edition of the reviewed Glossary was published by the UAO in 2016 as part of the "Creating and Implementing National Professional Standards for Evaluators" project.

According to the Glossary of Monitoring and Evaluation Terms of the Ukrainian Association for the Evaluation of Policies, Programs and Projects, the term "Evaluation" is closer to the concept of forming a judgment or conclusion, as opposed to the term "Assessment", which reflects the processes of collecting and analyzing raw data (indicators) with appropriate calculations.

In the real national economy, the term "Assessment" is used in the government and public sectors, while in academia academics and researchers use the term "Evaluation" more frequently. The term "Assessment" is usually used for the result reflecting the action performed, and the term "Evaluation" is used for the action itself, i.e., monitoring.

The substantiated monitoring of initial indicators of information support of methodological approaches to the assessment of the target criterion of the complex regulatory impact of the state on the activities of banks is shown in Table 1 .

Based on the subject, object and purpose of the study, the following terms and concepts of the Glossary for UAO monitoring and evaluation were used: indicator, impact, activity, monitoring, outcome monitoring, evaluation, impact evaluation, process evaluation, outcome evaluation, rating.

\section{Measures of regulatory influence of the state on the activity of banks}

Defining the range of values of the level of probability of bankruptcy, which is the inverse 
Table 1

Monitoring of initial indicators of methodological approaches to the assessment of the target criterion of the complex regulatory impact of the state on the activities of banks

\begin{tabular}{|c|c|c|c|}
\hline Comparative & Option & Income & Property \\
\hline $\begin{array}{l}\text { Regulatory capital adequacy } \\
(\mathrm{H} 2)^{* *}\end{array}$ & Market value of assets & Interest income and expense & Money and its equivalents \\
\hline Book value of capital * & Extent of obligations & $\begin{array}{l}\text { Operating income and } \\
\text { expenses }\end{array}$ & Loan portfolio \\
\hline Balance sheet assets * & Pay back & $\begin{array}{l}\text { Deductions from the bad debt } \\
\text { provision }\end{array}$ & Deposit portfolio \\
\hline Provision of liquidity ** & $\begin{array}{l}\text { Volatility of the relative } \\
\text { change in the return on assets } \\
*\end{array}$ & Investment income & Investment portfolio \\
\hline Loan portfolio ${ }^{* *}$ & $\begin{array}{l}\text { Volatility of the relative } \\
\text { change in the net spread }\end{array}$ & Level of regulatory capital & $\begin{array}{l}\text { Bank liabilities other than } \\
\text { deposits }\end{array}$ \\
\hline Level of loan provisioning ** & $\begin{array}{l}\text { Volatility of the relative } \\
\text { change in the net interest } \\
\text { margin }{ }^{* *}\end{array}$ & Net cash flow & $\begin{array}{l}\text { The likelihood of satisfying } \\
\text { claims on the unsecured } \\
\text { portion of the loan } \\
\text { indebtedness }\end{array}$ \\
\hline Net income ${ }^{*}$ & - & Discount rate & - \\
\hline Provision of liquidity ${ }^{*}$ & - & Capitalization rate & - \\
\hline
\end{tabular}

* Indicators proposed by Ukrainian scientists.

** Additional indicators that are justified by the author

Source: compiled by the author

value of the integral indicator of the financial condition of the bank, more differentiated defines classes of banks on the leading indicators of regulatory impact on banking activity.

Using the range of default ratio values for debtor banks according to the Resolution of the National Bank of Ukraine No. 351 of 30.06.2016 (with additions and clarifications) to determine the debtor class are shown in Table 2.

The use of the range of values of the level of probability of bankruptcy more differentiated defines classes of banks by the level of financial condition and groups of banks at risk of bankruptcy. At the same time the signs of determining the level of bank's financial condition are adequate to the aggregate criteria of determining their financial stability: high (absolute stability), sufficient (normal stability), average (unsta- ble), unstable (crisis resilience). Typical measures of regulatory influence are given in table 3 .

Monitoring the effectiveness of the comprehensive regulatory impact of the state on the activities of banks is advisable to conduct an authorized employee of the National Bank of Ukraine once a year, and repeated monitoring on a quarterly basis if there are signs of unstable financial condition of the entire banking system of Ukraine.

The presence of signs of unstable financial condition of the banking system, as well as the circumstances that threaten the stability of the banking and/or financial system of the country, is confirmed by the relevant decision of the Financial Stability Council, the powers of which are determined by the Decree of the President of Ukraine (Verkhovna Rada of Ukraine, 1999).

Table 2

The ranges of debtor or counterparty bank's P-D ratios for funds deposited with other resident banks

\begin{tabular}{|c|c|c|}
\hline № & Class of counterparties for funds placed in other banks & The ranges of values of the coefficient of probability \\
\hline 1 & 1 & $0,005-0,06$ \\
\hline 2 & 2 & $0,07-0,12$ \\
\hline 3 & 3 & $0,13-0,20$ \\
\hline 4 & 4 & $0,21-0,99$ \\
\hline 5 & 5 & 1,0 \\
\hline
\end{tabular}

Source: Resolution of the National Bank of Ukraine dated June 30, 2016. № 351 
Table 3

Classification of typical measures of monitoring the effectiveness of the regulatory impact of the state on the activities of banks

\begin{tabular}{|c|c|c|l|}
\hline № & $\begin{array}{c}\text { Group and type of bank } \\
\text { by financial condition }\end{array}$ & $\begin{array}{c}\text { Class of banks according to } \\
\text { the level of financial condition }\end{array}$ & \multicolumn{1}{|c|}{ Regulatory influence measures } \\
\hline 1 & Stable & High & Monitoring and testing economic standards \\
\hline 2 & Stable & Sufficient & Monitoring and revising economic standards \\
\hline 3 & Problematic & Average & Revaluation of bank assets (loans and securities portfolio) \\
\hline 4 & Crisis & Unstable & Introduction of a bank supervisor to control active operations \\
\hline 5 & Bankruptcies & Default & Introduction of temporary administration \\
\hline
\end{tabular}

Source: developed by the author

The use of dynamic models of discriminant analysis to assess the financial condition of banks and the probability of bankruptcy will provide methodological continuity of methodological support for monitoring and evaluation components of the complex regulatory impact of the state on the activities of banks. The introduction of the new conceptual approach makes it impossible to conduct an artificial bankruptcy with the withdrawal of liquid assets of banks and ensures their stable operation with timely fulfillment of obligations to depositors, shareholders and creditors.

\section{Conclusions}

The determination of the regulatory impact of the state on the activities of banks in the framework of mandatory economic standards is not fully consistent with its market characteristics as an economic category.

It was objectively necessary, first, to expand national regulation by testing the leading indicators (the level of financial condition of banks and the degree of bankruptcy risk); second, to normalize the target criterion of regulatory impact (the market value of banks by their groups, types and classes). It is on these components of a complex regulatory influence of the state on the activities of banks appropriate to conduct their ratings not only the National Bank of Ukraine, but also the Independent Association of the Banks of Ukraine as a non-governmental organization.

One of the results of the assessment of the market value of the bank, as a target criterion for a comprehensive regulatory impact on banking activities, was a real opportunity to improve the effectiveness of crisis management, in particular:
- to quantify the potential level of the bank's financial condition and the degree of bankruptcy risk in order to justify the need for current and strategic adjustments to its activities;

- to the adequacy of methodological approaches and methods to measure market value using fuzzy logic;

- to conduct a clearer classification of banks on the basis of financial condition and the degree of risk of bankruptcy as leading indicators of regulatory impact, as well as to quantify and identify the specific characteristics of each group based on a discriminatory analysis.

The logical scheme of forming the target criterion of complex regulatory impact consists of a qualitative analysis of the level of financial condition and the degree of bankruptcy risk of the assessed bank to classify it into a group of banks with acceptable or unacceptable risk of bankruptcy with the subsequent choice of methodological approach and methods to assess its market value.

The market value of the bank with a satisfactory level of financial condition and acceptable degree of bankruptcy risk as a target criterion of regulatory impact of the state on banking activity should be calculated by discounted cash flows, capital market method and using Black-Scholes model, and for banks with an unsatisfactory level of financial condition and unacceptable degree of bankruptcy risk it is appropriate to apply property approach using asset accumulation method.

In the context of European integration of the national economy, it is proposed to introduce a clarifying standard for assessing the market value of bank assets as part of the regulatory impact of the state on banking activities, which will help to determine their market value in accordance with the opportunities and constraints of the internal market of financial services. 


\section{References:}

Artemenko, D. M. (2019). Otsinka vartosti yak ekonomichnoi katehorii [Valuation as an economic category]. Upravlinnia ekonomikoiu: teoriia ta praktyka. Vosmi Chumachenkivski chytannia zb. nauk. prats - Management of the economy: theory and practice. Eight Chumachenko readings coll. science. proceedings. Kyiv: NAS of Ukraine, Institute of Industrial Economy. (in Ukrainian)

Artemenko, D. M. (2021). Otsinka providnykh indykatoriv rehuliatornoi polityky derzhavy u bankivskomu sektori [Evaluation of leading indicators of state regulatory policy in the banking sector]. Visnyk ekonomichnoi nauky Ukrainy - Bulletin of Economic Science of Ukraine, 1(40), pp. 147-152. (in Ukrainian)

Pro Natsionalnyi bank Ukrainy: Zakon Ukrainy vid 20.05.1999 r. № 679-XIV [On the National Bank of Ukraine: Law of Ukraine of 20.05.1999 № 679-XIV]. Verkhovna Rada of Ukraine. Available at: https://zakon.rada.gov.ua/laws/show/679-14\#Text (in Ukrainian)

Osadcha, N. V., \& Artemenko, D. M. (2020). Otsinka tsilovoho kryteriiu i providnykh indykatoriv rehuliatornoho vplyvu u bankivskomu sektori [Evaluation of the target criterion and leading indicators of regulatory influence in the banking sector]. Upravlinnia ekonomikoiu: teoriia ta praktyka. Chumachenkivski chytannia: zb. nauk. prats - Economic Management: Theory and Practice. Chumachenko's readings: collection. science. proceedings. Kyiv: NAS of Ukraine, Institute of Industrial Economy. (in Ukrainian)

Lyashenko, V. I. (2012). Fynansovo-rehuliatornue rezhymy stymulyrovanyia ekonomycheskoho razvytyia: vvedenye v ekonomycheskuiu rezhymolohyiu: monografiya [Financial and regulatory regimes to stimulate economic development: an introduction to economic regime: monograph]. Donetsk: NAS of Ukraine, Institute of Industrial Economy. (in Russian)

Wallison, Peter J. (2011). Why the Left is Losing the Argument over the Financial Crisis / American Enterprise Institute, December 27, 2011.

Basel Committee on Banking Supervision / Basel III: The Liquidity Coverage Ratio and Liquidity Risk Monitoring Tools, January 2013. Available at: http://www.bis.org/publ/bcbs238.htm

European Central Bank. Aggregate Report on the Comprehensive Assessment / ECB, October 2014. Available at: https://www.ecb.europa.eu/pub/pdf/other/aggregatereportonthecomprehensive assessment201410.en.pdf 